\title{
DINAMIKA DALIL HUKUM HAKIM DALAM PENETAPAN PERMOHONAN DISPENSASI NIKAH DI PENGADILAN AGAMA NGANJUK TAHUN 2015
}

\author{
Dwi Siswanto \\ Jl. Jeruk, Wage, Taman, Sidoarjo. Email: \\ siswantouinsby@gmail.com
}

\begin{abstract}
The article soughts to answer the questions of the judge's judicial considerations, the difference between the use of Judge's judicial consideration and the review of Islamic law on the application of a marriage dispensation in Nganjuke. Religious Court of 2015. The fact says that the judge's judicial consideration is not only based on the available provisions, but also using the approach of a methodology called maslahah mursalab against an unwed pregnancy, regarding the difference usage of the judicial consideration is merely as the basis of the judge's stipulation. It is because the application uses a legal counsel and the provisions on the aborted and revoked petition. The judge's legal evidence is in accordance with Islam. The result of the research states that the judge's legal considerations are not only guided by the available provisions but also the methodology of maslahah mursalah in Islamic law. If the judge's judicial considerations are in accordance with Islamic law, the Petitioner's petition should be accepted.
\end{abstract}

Keywords: Legal consideration, dispensation of marriage and maslabah mursalah.

Abstrak: Penelitian ini bertujuan menjawab pertanyaan tentang dalil hukum hakim, perbedaan penggunaan dalil hukum Hakim dan tinjauan hukum Islam terhadap penetapan permohonan dispensasi nikah di Pengadilan Agama Nganjuk Tahun 2015. Proses penelitian yang dilakukan menemukan bahwa pertimbangan hukum hakim tidak hanya berpedoman pada ketentuan yang berlaku, melainkan menggunakan pendekatan metodologi pengkajian hukum Islam yang disebut maslahab mursalab terhadap wanita hamil di luar nikah. Mengenai terjadinya perbedaan penggunaan dalil hukum hakim hanya sebagai dasar hukum hakim dalam penetapannya dikarenakan pada permohonan tersebut menggunakan penasehat hukum dan ketentuan mengenai permohonan yang digugurkan dan dicabut. Dalil hukum hakim sesuai dengan Islam. Kesimpulan yang diperoleh menyatakan bahwa pertimbangan hukum hakim tidak hanya berpedoman pada ketentuan yang berlaku, melainkan majelis hakim, menggunakan pendekatan metodologi pengkajian hukum Islam, maslahah mursalah, dan pertimbangan terhadap perlindungan dan kepastian hukum terhadap keberadaan anak, terhadap wanita hamil diluar 
nikah, mengenai terjadinya perbedaan penggunaan dalil hukum hakim hanya sebagai dasar hukum penetapan dikarenakan pada permohonan tersebut menggunakan penasehat hukum dan ketentuan mengenai permohonan yang digugurkan dan dicabut, dalil hukum hakim sudah sesuai dengan Islam, maka permohonan Pemohon patut diterima.

Kata Kunci: Dalil Hukum, Dispensasi Nikah, Maslahah Mursalah

\section{Pendahuluan}

Pernikahan dini merupakan suatu antisipasi dari orang tua untuk mencegah timbulnya akibat negatif yang merusak dan mencemarkan nama baik serta martabat keluarga. Antisipasi orang tua ini diwujudkan dalam bentuk proses pendampingan melegalkan atau memperoleh bukti akta pernikahan dari lembaga yang berwenang proses ini dilakukan di Pengadilan Agama.

Berdasarkan ketentuan Pasal 7 ayat (1) UU No. 1 Tahun 1974 tentang Perkawinan "perkawinan hanya diizinkan jika pihak pria sudah mencapai umur 19 (Sembilan belas) tahun dan pihak wanita sudah mencapai usia 16 (enam belas) tahun". Penentuan batas usia minimum seseorang boleh melakukan pernikahan sangatlah penting, sebab pernikahan sebagai sesuatu perjanjian perikatan antara seorang pria dan wanita sebagai suami istri. Oleh sebab itu pernikahan seharusnya dilakukan oleh pasangan yang sudah siap baik dilihat dari biologis dan spikologis.

Berdasarkan persyaratan seseorang boleh melakukan pernikahan yang salah satunya adalah memenuhi batas usia pernikahan, bilamana belum memenuhi batas usia pernikahan maka dapat memohon izin dispensasi nikah kepada Pengadilan Agama. Ketentuan tersebut diatur dalam Pasal 7 ayat (2) UU No. 1 Tahun 1974 tentang Perkawinan "dalam hal penyimpangan terhadap ayat (1) pasal ini dapat meminta dispensasi nikah ke pengadilan agama atau pejabat lain yang berwenang ditunjuk oleh salah kedua orang tua pihak pria maupun pihak wanita".

Menurut madzab Syafii ketentuan balig bagi anak laki - laki ditandai dengan mimpi basah, sesuatu yang menyebabkan keluarnya air mani, hal ini sering kali terjadi pada perkiraan usia 15 tahun. Sedangkan pada anak perempuan ketentuan balig ditandai dengan menstruasi minimal dapat terjadi pada anak perempuan 
usia 9 tahun. Ketentuan bagi anak perempuan juga bisa dikenakan sebab mengandung (hamil).

Bilamana tidak terdapat indikasi/tanda balig pada anak lakilaki maupun anak perempuan maka ketentuan balig ditentukan dengan usia. Menurut Imam Abu Hanifah berpendapat bahwa usia pada anak laki-laki 18 tahun sedangkan untuk anak perempuan usia 17 tahun sementara Abu Yusuf Muhammad bin Hasan dan madzab Syafii berpendapat usia 15 tahun adalah tanda balig bagi laki-laki maupun perempuan.

Meskipun sudah ada batas minimum seseorang boleh melakukan pernikahan, ada kelonggaran untuk terjadinya pernikahan yang menyimpang dari ketentuan asalkan ada dispensasi nikah dari Pengadilan Agama berdasarkan ketentuan Pasal 7 ayat (2) UU No.1 Tahun 1974 tentang Perkawinan "dalam hal penyimpangan terhadap ayat (1) pasal ini dapat meminta dispensasi nikah ke Pengadilan Agama atau pejabat lain yang berwenang ditunjuk oleh salah kedua orang tua pihak pria maupun pihak wanita".

Pengadilan Agama mempunyai kewenangan absolut untuk menerima, memeriksa dan memutuskan perkara hukum perdata Islam salah satunya permohonan dispensasi nikah. Pertimbangan hukum hakim dalam putusan maupun penetapan perkara di lingkungan Peradilan Agama dibagi menjadi dua, pertimbangan tentang duduk perkara atau peristiwa dan pertimbangan tentang hukum, dalam hal ini para pihak menjelaskan duduk perkara atau peristiwa sedangkan hakim menjelaskan tentang hukum dan dituangkan dalam bentuk tulisan yang berupa putusan maupun penetapan. Pengadilan Agama Nganjuk merupakan Pengadilan tingkat pertama dibawah naungan Mahkamah Agung. Pengadilan Agama Nganjuk tahun 2015 memberikan penetapan permohonan dispensasi nikah sejumlah 44 permohonan dispensasi nikah, dari 44 permohonan dispensasi nikah 1 permohonan dispensasi nikah digugurkan dikarenakan Pemohon tidak hadir saat persidangan dan 1 permohonan dispensasi nikah dicabut oleh Pemohon.

Majelis hakim telah beralasan untuk mengesampingkan ketentuan batas usia minimum usia pernikahan yang telah diatur dalam ketentuan Pasal 7 ayat (1), UU No.1 Tahun 1974 tentang 
Perkawinan, Jo pasal 15 ayat (1) Kompilasi Hukum Islam di Indonesia dalam hal ini memberikan sebuah kelemahan terhadap ketentuan pasal 7 ayat (1) UU No. 1 Tahun 1974 tentang Perkawinan, Jo Pasal 15 Kompilasi Hukum Islam di Indonesia, bilamana semua permohonan dispensasi nikah dikabulkan. Berdasarkan pemaparan di atas, peneliti tertarik untuk meneliti lebih lanjut mengenai permasalahan dalil hukum hakim dalam memberikan penetapan permohonan dispensasi nikah di Pengadilan Agama Nganjuk Tahun 2015.

\section{Pengertian Dispensasi Nikah}

Secara sederhana pengertian dispensasi nikah dapat dipahami dalam dua kata dasar dispensasi dan nikah, dalam kamus besar bahasa Indonesia arti dispensasi adalah pengecualian dari aturan umum untuk suatu keadaan yang khusus pembebanan dari suatu kewajiban atau larangan, menyatakan bahwa suatu peraturan perundang - undangan tidak berlaku untuk suatu hal yang khusus. ${ }^{1}$

Adapun pernikahan menurut UU No.1 Tahun 1974 tentang Perkawinan dapat diartikan sebagai berikut "perkawinan ialah ikatan lahir batin antara seorang pria dan wanita sebagai suami istri dengan tujuan membentuk keluarga (rumah tangga )yang bahagia dan kekal berdasarkan ketuhanan Yang Maha Esa". ${ }^{2}$

Berdasarkan penjelasan mengenai makna dispensasi nikah diatas dalam Islam tidak mengartikan secara spesifik mengenai makna dispensasi nikah, dikarenakan dalam Islam belum dijelaskan secara pasti mengenai batas usia seseorang boleh melakukan pernikahan, asalkan antara calon suami maupun calon isteri telah balig.

\section{Dispensasi Nikah dalam Kontruksi Hukum Positif}

Berdasarkan ketentuan Pasal 7 ayat (1) UU No. 1 Tahun 1974 tentang Perkawinan "perkawinan hanya diizikan jika pihak pria sudah mencapai umur 19 (Sembilan belas) tahun dan pihak wanita sudah mencapai umur 16 (enam belas) tahun. ${ }^{3}$ Persyaratan

1 Tim Penyususunan dan Pengembangan Bahasa, Kamus Besar Bahasa Indonesia, (Jakarta: Balai Pustaka, 1988), 270.

${ }^{2}$ Pasal 1 Undang -undang No.1 Tahun 1974 tentang Perkawinan.

${ }^{3}$ Ibid., Pasal 7 ayat (1). 
tersebut juga dipertegas dalam ketentuan Pasal 15 ayat (1) Kompilasi Hukum Islam "untuk kemaslahatan keluarga dan rumah tangga perkawinan hanya boleh dilakukan calon mempelai yang telah mencapai umur yang ditetapkan dalam pasal 7 Undang undang No.1 Tahun 1974 yakni calon suami sekurang - kurangnya berumur 19 tahun dan calon isteri sekurang - kurangnya berumur 16 tahun".

Berdasarkan ketentuan Pasal 7 ayat (2) UU No. 1 Tahun 1974 tentang Perkawinan "dalam hal penyimpangan terhadap ayat (1) pasal ini dapat meminta dispensasi nikah ke Pengadilan Agama atau pejabat lain yang berwenang ditunjuk oleh salah kedua orang tua pihak pria maupun pihak wanita". ${ }^{5}$ Mengenai halnya dengan permohonan dispensasi nikah Pasal 4 ayat (1) UU No. 3 Tahun 2006 tentang Peradilan Agama, menyatakan bahwa permohonan dispensasi nikah dapat diajukan berdasarkan daerah hukum tempat tinggalnya pemohon yang terletak di kabupaten $/$ kota. $^{6}$

\section{Dispensasi nikah dalam kontruksi hukum Islam}

Dalam perpektif hukum Islam memiki resepsi yang berbeda mengenai makna dispensasi nikah, dalam kontruksi hukum Islam dispensasi nikah dapat diartikan sebagai sebuah keadaan yang merubah keadaan sebuah hukum asal, misalnya dalam Islam memiliki metode maslahah mursalah yaitu maslahah yang tidak ada legalitas hukumnya posisi yang tidak ada legalitas hukumnya dalam halnya mengenai makna dispensasi nikah dalam kontruksi hukum Islam, maka konsep maslahah inilah yang dapat dijadikan salah satu dalil dalam penggalilan hukum Islam perpektif ulama ushul fikih mengenai makna dispensasi nikah. ${ }^{7}$ Pernikahan dalam Islam memanglah sangat dianjurkan berpedoman dari alqur'an dalam surah Annisa ayat 32:

"Dan kawinkanlah orang-orang yang sedirian diantara kamu, dan orangorang yang layak. (berkawin) dari hamba-hamba sabayamu yang lelaki dan hamba-hamba sahayamu yang perempuan. jika mereka miskin Allah akan

${ }^{4}$ Pasal 15 ayat 1 Kompilasi Hukum Islam.

${ }^{5}$ Pasal 7 ayat (2), Undang - undang No. 1 Tahun 1974 tentang Perkawinan.

${ }^{6}$ Pasal 4 ayat (1) Undang- undang No.3 Tahun 2006 tentang Peradilan Agama.

${ }^{7}$ Asafri Jaya Bakti,Konsep Maqa\}sid Syariah al- Syatibi, (Jakarta: Raja GrafindoPersada, 2002), 145. 
memampukan mereka dengan kurnia-Nya. dan Allah Maba Luas (pemberian-Nya) lagi Maha mengetabui. ${ }^{, 8}$

Berdasarkan ayat di atas kata (الصالحين) dapat dipahami oleh banyak ulama dalam arti "yang layak kawin" yakni yang mampu secara mental dan spiritual untuk membina rumah tangga. ${ }^{9}$ Begitu pula dengan Hadist Rasulullah Saw, yang menganjurkan kepada para pemuda untuk melangsungkan pernikahan dengan syarat adanya kemampuan bila belum mampu hendaknya berpuasa.

"Dari 'Aisyah, Dia berkata Rasulullah SAW bersabda: Nikah itu sebagian dari sunabku, barang siapa yang tidak mau mengamalkan sunabku, maka dia bukan termasuk golonganku. Dan menikablah kalian semua, sesunggubnya aku (senang) kalian memperbanyak umat, dan barang siapa (diantara kalian) telah memiliki kemampuaan atau persiapan (untuke menikah) maka menikahlah, dan barang siapa yang belum mendapati dirinya (kemampuan atau kesiapan) maka hendaklah ia berpuasa, sesunggubnya puasa merupakan pemotong hawa nafsu baginya." "10

Berdasarkan Hadist di atas bahwa Rasullah Saw, menganjurkan menikah bagi para pemuda yang telah sanggup melangsungkan pernikahan. Dalam Hadist tersebut tidak ada kreteria usia pernikahan, hanya disebutkan bagi mereka yang sudah mampu, karena pernikahan merupakan ikatan yang sakral antara seorang pria dan wanita. Pernikahan merupakan pembeda antara hubungan sah suami istri dan berbuat zina. Sedangakan bagi mereka yang belum mampu hendaklah berpuasa. Selanjutnya mayoritas ulama fikih mengesahkan terjadinya perkawinan dini, berpedoman pada alqur'an Surah attalaq Ayat 4 mengenai masa idah (masa menuggu) bagi perempuan yang mengalami menopause dan perempuan yang belum haid.

8 Departemen Agama RI, Al-Qur'an dan Terjemahnya, (Bandung: CV Penerbit JArt, 2005), 354.

9 M. Quraish Shihab, Tafsir al Misbāh, Vol. IX, (Jakarta : Lentera Hati, 2005), 335.

10 Abu Abdullah Muhammad bin Yazid bin Majah ar-Rabi'i al-Qarwini, Sunan Ibn Majah Juz 1, (Beirut, Libanon: Daarul Kutub al-'Ilmiah, 275 H), 592. 
"Dan perempuan-perempuan yang tidak haid lagi (monopause) di antara perempuan-perempuanmu jika kamu ragu-ragu (tentang masa iddahnya), Maka masa iddah mereka adalah tiga bulan; dan begitu (pula) perempuanperempuan yang tidak haid. dan perempuan-perempuan yang bamil, waktu iddah mereka itu ialah sampai mereka melabirkan kandungannya. dan barang -siapa yang bertakwa kepada Allah, niscaya Allah menjadikan baginya kemudahan dalam urusannya."11

Ayat ini menjelaskan mengenai masa idah (masa menuggu) bagi perempuan yang mengalami menopause dan perempuan yang belum haid. Masa iddah bagi kedua kelompok perempuan ini adalah tiga bulan. Secara tidak langsung ayat ini mengandung makna bahwa pernikahan bisa dilaksanakan pada perempuan beliu usia (muda), karena idah hanya bisa dikenakan kepada seorang wanita yang sudah kawin dan bercerai. ${ }^{12}$

\section{Akibat Hukum Dispensasi Nikah}

Berdasarkan ketentuan Pasal 7 ayat (2) UU No.1 Tahun 1974 tentang Perkawinan, memberikan dorongan lebih luas terjadinya perkawinan diusia dini, perlu dipahami sejauh mana dispensasi atas suatu peraturan dapat dilakukan, harus diketahui pula tujuan yang hendak dicapai oleh peraturan yang mendasari tersebut, Pasal 7 ayat 2 UU No.1 Tahun 1974 tentang Perkawinan, mengatur mengenai penyimpangan terhadap batas usia minimum untuk seorang boleh melakukan pernikahan, yakni 19 (Sembilan belas) tahun untuk pria dan 16 (enam belas) tahun untuk wanita.

Berdasarkan penjelasan Pasal 7 ayat (1) UU No.1 Tahun 1974 tentang perkawinan, dikatakan tujuan yang hendak dicapai dari ditetapkannya batas usia perkawinan guna menjaga kesehatan suami istri maupun keturunannya. Oleh sebab itu Pasal 7 ayat (2) UU No.1 Tahun 1974 tentang Perkawinan membuka praktek terjadinya pernikahan diusia dini. Konsekuensinya, apabila semua permohonan dispensasi nikah di Pengadilan Agama dikabulkan telah memperparah kondisi kualitas pertumbuhan anak di Indonesia karena akan kehilangan akses terhadap pendidikan dan

${ }^{11}$ Departemen Agama RI, Al- Quran dan terjemahan ...,559.

12 Husain Muhammad, Fiqib Perempuan Refleksi Kiai Atas Wacana Agama dan Gender, (Jogjakarta: LKiS, 2007), 91. 
kesempatan untuk dapat berkembang dan memahami tanggung jawab dalam perkawinan sebelum melakukan perkawinan tersebut.

\section{Kepastian hukum dengan adanya dispensasi nikah}

Pada dasarnya permohonan dispensasi nikah di Pengadilan Agama, untuk memperoleh adanya kepastian hukum atau pembuktian secara yuridis mengenai hukum yang ditimbulkan dengan adanya perkawinan bagi mereka yang usianya belum mencapai usia minimal seseorang boleh melakukan pernikahan yang di atur dalam ketentuan Pasal 7 ayat (1) UU No.1 Tahun 1974 tentang Perkawinan.

Berdasarkan kitab Undang - undang hukum Perdata Burgerlijk Wetboek (BW) ketentuan Pasal 1865 BW tentang Pembuktian, menyatakan sebagai berikut "setiap orang yang mendalilkan bahwa ia mempunyai suatu hak, atau guna meneguhkan haknya sendiri maupun membatah suatu hak orang lain, menunjukkan pada suatu peristiwa, diwajibkan membuktikan adanya hak tau peristiwa tersebut". ${ }^{13}$

Berdasarkan hukum perkawinan pembuktian hanya bisa dibuktikan dengan adanya surat kutipan akta nikah, mendapatkan pengakukan secara hukum dalam mendapatkan bukti otentik dari pernikahan yang dilangsungkan, hal ini dilakukan berkaitan dengan masalah keperdataan dalam akibat hukum yang ditimbulkan dengan adanya pernikahan, karena dalam mengurus masalah adminitrasi yang berkaitan dengan akibat hukum yang ditimbulkan dengan adanya pernikahan harus menunjukkan adanya akta pernikahan. $^{14}$

Berdasarkan perlindungan dan kepastian hukum terhadap asal asul anak akibat hukum selanjutnya mengenai perkawinan yang sah, adanya kepastian hukum antara hubungan antara orang tua dan anak. Berdasarkan dengan adanya kepastian hukum dengan adanya dispensasi nikah, maka pernikahan hanya dapat dibuktikan dengan adanya akta nikah sebagai bukti otentik. Akta nikah berguna bagi kedua belah pihak, misalnya dengan adanya akta

13 Pasal 1865 BW.

14 Moh Zahid, Dua Pulub Tahun Pelaksanaan Undang - undang Perkawinan, (Jakarta: Departemen Agama RI Badan Litbang Agama dan Diklat Keagamaan, 2002), 72. 
nikah dapat dijadikan bukti bahwa mereka telah melaksanakan pernikahan secara sah menurut hukum Islam maupun UU No.1 Tahun 1974 tentang Perkawinan.

\section{Proses Pengajuan Dispensasi Nikah}

Mengenai prosedur permohoan dispensasi nikah di Pengadilan Agama sudah diatur sesuai dengan ketentuan Pasal 7 ayat (1) UU No.1 Tahun 1974 tentang Perkawinan "perkawinan hanya diizinkan apabila pihak pria sudah mencapai umur 19 (Sembilan belas) tahun dan pihak wanita sudah mencapai umur 16 (enam belas) tahun." Dalam hal penyimpangan terhadap ayat (1) pasal ini dapat meminta dispensasi nikah kepada Pengadilan Agama atau pejabat lain yang ditunjuk oleh kedua orang tua pihak pria maupun pihak wanita." 15

Berdasarkan ketentuan Pasal 4 UU No.7 Tahun 1989 di ubah dengan UU No.3 Tahun 2006 tentang Peradilan permohonan dispensasi nikah ke Pengadilan Agama berdasarkan daerah hukumnya pemohon yang berkedudukan di Ibu kota Kabupaten atau kota. ${ }^{16}$ Ketentuan dan persyaratan tentang tata cara menyusun surat permohonan sudah di atur dalam Rv Pasal 8 No.3 menyebutkan bahwa dalam surat permohonan harus pokok permohonan yang meliputi.

1. Identitas Pemohon, anak pemohon dan calon suami atau calon istri anak pemohon, identitas terdiri dari (Nama, Umur, Agama, Pekerjaan dan Alamat tinggal).

2. Posita yaitu penjelasan tentang keadaan atau peristiwa dan penjelasan yang berhubungan dengan hukum yang dijadikan dasar atau alasan permohonan.

3. Potitum yatu tuntutan yang diminta oleh pemohon agar dikabulkannya permohonan pemohon oleh Majelis Hakim. ${ }^{17}$

Permohonan tersebut diajukan ke Pengadilan Agama setelah kehendak melangsungkan pernikahan ditolak oleh Pegawai

15 Pasal 7 ayat (1) dan ayat (2) Undang- undang No.1 Tahun 1974 tentang Perkawinan.

16 Pasal 4 UU No.3 Tahun 2006 atas perubahan UU No No.7 Tahun 1989 tentang Peradilan Agama.

17 Mukti Arto, Praktek Peradilan Pada Pengadilan Agama, (Yogjakarta: Pustaka Pelajar, 2006), 41-42. 
Pencatatan Nikah (PPN) Kantor Urusan Agama, dengan alasan salah satu atau kedua calon mempelai usianya belum memenuhinya persyaratan usia pernikahan. ${ }^{18}$ Pengajuan permohonan dispensasi nikah ke Pengadilan Agama harus memenuhi prosedur dan tata cara dalam mengajukan permohonan dispensasi nikah di Pengadilan Agama antara lain

1. Meja 1

Surat permohonan yang telah di buat dan di tandatangani ditunjukan pada kepeniteraan permohonan, pemohon menghadap pada meja satu yang akan menaksirkan besarnya panjar biaya perkara dan menuliskan pada surat kuasa untuk membayar (SKUM) yang harus dibayar oleh pemohon kepada Bank yang telah ditunjuk oleh Pengadilan Agama.

Dalam menafsirkan panjar biaya perkara ketua Pengadilan Agama harus merujuk peraturan mahkamah agung RI No. 53 Tahun 2008, peraturan Mahkamah Agung No 3 tahun Tahun 2012 tentang biaya proses penyelesaian perkara dan pengelolaannya pada Mahkamah Agung dan badan peradilan yang berada di bawahnya serta peraturan terkait lainnya. ${ }^{19}$ Mengenai ketentuan mengenai menaksirkan panjar biaya perkara perlu diperhatikan hal - hal sebagai berikut:

a. Jumlah pihak yang berperkara

b. Jarak tempat tinggal dan kondisi daerah para pihak (radius). ${ }^{20}$

Ketentuan biaya perkata sudah di atur dalam Pasal 90 No.7 Tahun1989 diubah dengan UU No.3 Tahun 2006 tentang Peradilan Agama sehingga pasal 90 berisi sebagai berikut;

a. Biaya kepaniteraan dan biaya materai yang diperlukan untuk perkara tersebut.

b. Biaya untuk para saksi, saksi ahli, penerjemah, dan biaya pengambilan sumpah yang diperlukan dalam perkara tersebut

18 Ibid.

19 Pedoman Pelaksaan Tugas dan Adminitrasi Peradilan Agama Edisi Revisi, Buku II, (Direktoral Jenderal Badan Peradilan Agama, 2010), 2.

${ }^{20}$ Ibid., 2. 
c. Biaya yang diperlukan untuk melakukan pemeriksaan setempat dan tindakan - tindakan lain yang diperlukan pengadilan dalam perkara tersebut

d. Biaya pemanggilan, pemberitahuan, dan lain -lain atas perintah pengadilan yang berkenaan dengan perkara tersebut. $^{21}$

Kemudian Pemohon menghadap kepada kasir dengan menyerahkan surat permohonan dan surat kuasa untuk membayar (SKUM), kemudian petugas kasir melakukan proses sebagai berikut:

a. Menerima bukti pembayaran yang telah dilakukan oleh pemohon tersebut dan mencatat dalam jurnal biaya perkara, menandatangani dan memberikan nomor perkara serta tanda lunas pada SKUM.

b. Mengembalikan surat permohonan dan SKUM kepada pemohon. ${ }^{22}$

2. Meja II

Pemohon kemudian menghadap pada meja II dengan menyerahkan surat permohonan dan SKUM yang telah dibayar. Kemudian petugas meja II melakuan proses sebagai berikut:

a. Memberikan nomor pada surat permohonan sesuai dengan yang telah diberikan oleh kasir. Sebagai tanda telah terdaftar maka meja II melakukan paraf.

b. Menyerahkan atau lembar surat permohonan yang telah terdaftar bersama satu helai SKUM kepada pemohonan. Kepada para pihak diberitahukan pula bahwa mereka dapat mempersiapkan bukti - bukti yang diajukan dalam persidangan. ${ }^{23}$

Setelah berkas permohonan dispensasi nikah di Meja II, kemudian berkas perkara diserahkan kepada Ketua Pengadilan Agama oleh Wakil Panitera untuk diperiksa kelengkapan

21 Pasal 90, UU No 7 Tahun 1989 diubah dengan UU No. 3 Tahun 2006, Tentang Peradilan Agama.

22 Mukti Arto, Praktek Perkara Perdata pada Peradilan Agama, (Jogjakarta, Pusta Pelajar, 1996), 28

${ }^{23}$ Ibid., 28. 
formilnya. ${ }^{24}$ Kemudian Ketua Pengadilan Agama kemudian membuat penetapan majelis hakim dan dikembalikan kepada panitera, kemudian panitera menunjuk panitera sidang atau panitera pengganti. Majelis hakim membuat penetapan hari sidang serta mengembalikan berkas kepada Meja II, kemudian Meja II membuat surat penggilan kepada pemohon dan calon mempelai yang akan dimintakan dispensasi nikah beserta saksi guna untuk meperkuat permohonan pemohon. Setelah menyidangkan perkara, dengan pertimbangan hukum yang ada dan sesuai dengan keadaan, serta keterangan - keterangan para saksi, maka majelis hakim memberikan penetapan berupa : -Menolak atau Mengabulkan permohonan Pemohon.

Apabila Majelis hakim mengabulkan permohonan dispensasi nikah tersebut, maka calon mempelai dapat mendaftarkan kembali ke Pegawai Pencatatan Nikah Kantor Urusan Agama Kecamatan guna untuk melengkapi salah satu kekurangan pesyaratan perkawinan mengenai batas usia perkawinan, kemudian dapat melangsungkan pernikahan. Bila mana Majelis hakim menolak, maka harus menunggu sampai umur mereka boleh untuk melakukan pernikahan. ${ }^{25}$

\section{Faktor - Faktor Penyebab Terjadinya Dispensasi Nikah}

Factor - faktor yang menjadikan banyaknya permohonan dispensasi nikah di pengadilan agama rata - rata karena hamil sebelum melangsungkan perkawinan. Faktor yang kedua yang sering dijadikan alasan untuk pengajuan dispensasi adalah karena telah terlalu dekat berhubungan atau menjalin cinta kasih (berpacaran), apabila tidak segera dilakukan perkawinan dikhawatirkan akan terjerumus ke jalan maksiat. Kekhawatiran itu bisa datang dari pihak yang akan menikah ataupun dari pihak kedua calon mempelai tersebut. ${ }^{26}$

Dari uraian diatas, ada dua faktor utama yang seringkali dijadikan alasan pengajuan dispensasi nikah ke Pengadilan Agama, yakni karena hamil diluar nikah dan takut melakukan maksiat

24 Umar Said, Hukum Acara Peradilan Agama, (Surabaya: Cempaka, 2004), 29.

${ }^{25}$ Ibid., 45.

${ }^{26}$ http:/ / pakjorong.blogspot.co.id/2011/05/wawancara-masalah-dispensasipernikahan.html?m=1, diakses pada 12 Juni 2016. 
karena hubungan yang sudah sangat dekat. Dengan demikian orang tua memohon kepada pengadilan agama agar mengizinkan anaknya yang usianya belum mencapai usia perkawinan.

\section{Penyelesaian Perkara Permohonan Dispensasi Nikah di Pengadilan Agama Nganjuk Tahun 2015}

Majelis hakim dalam menyelesaikan perkara permohonan dispensasi nikah di Pengadilan Agama Nganjuk Tahun 2015 terdapat 5 majelis hakim, kemudian majelis hakim memeriksa permohonan tersebut sesuai dengan ketentuan undang - undang yang belaku yang berpedoman pada ketentuan Pasal 7 ayat (2) UU No. 1 Tahun 1974 tentang Perkawinan "dalam hal penyimpangan terhadap ayat (1) pasal ini dapat meminta dispensasi nikah ke Pengadilan Agama atau pejabat lain yang berwenang ditunjuk oleh salah kedua orang tua pihak pria maupun pihak wanita". ${ }^{27}$

Berdasarkan surat Permohonannya Pemohon hendak menikahkan anak Pemohon, akan tetapi Pegawai Pencatatan Nikah (PPN) Kantor Urusan Agama Kecamatan, Kabupaten Nganjuk menolak dengan alasan anak Pemohon usianya masih dibawah ketentuan batas usia pernikahan, kemudian Pemohon mengajukan permohonan dispensasi nikah di Pengadilan Agama Nganjuk. ${ }^{28}$ Selanjutnya permohonan dispensasi nikah didaftarkan dalam register kepaniteraan permohonan Pengadilan Agama Nganjuk, berdasarkan ketentuan Pasal 390 HIR perkara permohonan tersebut harus diproses dalam waktu 14 (empat belas) hari kerja sejak permohonan didaftarkan, kemudian Pengadilan Agama Nganjuk memanggil Pemohan dan mendengarkan permohonannya. ${ }^{29}$

Pada sidang pertama pemeriksaan perkara permohonan dispensasi nikah, majelis hakim berusaha untuk menasehati kepada Pemohon agar membatalkan niatnya untuk tidak menikahkan anaknya yang masih dibawah batas usia pernikahan akan tetapi majelis hakim tidak berhasil. ${ }^{30}$ Maka selanjutnya dibacakan

\footnotetext{
${ }^{27}$ Pasal 7 Ayat (2) Undang - undang No. 1 Tahun 1974 tentang Perkawinan.

28 Ibid., Ayat (2).

${ }^{29}$ Pasal 390 HIR.

30 Perma No. 1 Tahun 2008, Upaya Mediasi, (Pasal 130 HIR/ 154 RBg).
} 
permohonan Pemohon kepada Pengadilan Agama Nganjuk yang intinya tetap dipertahankan oleh Pemohon.

Berdasarkan surat permohonan yang telah dibacakan di depan persidangan Pemohon tetap pada permohonannya, maka selanjutnya majelis hakim memeriksa persyaratan yang harus dipenuhi di dalam mengajukan permohonan dispensasi nikah di Pengadilan Agama Ngajuk

Berdasarkan persyaratan yang telah diajukan oleh Pemohon selanjutnya majelis hakim mendengarkan keterangan dari anak Pemohon beserta calon suami atau calon istri anak Pemohon, kemudian apabila calon istri sudah dalam keadaan hamil keduanya memberikan keterangan bahwa mereka telah melakukan hubungan intim layaknya suami istri dan saat ini calon istri dalam keadaan hamil. Keduanya memberikan keterangan bahwa keduanya siap untuk membina rumah tangga serta tidak mau pernikahan mereka ditunda - tunda karena tidak ingin terjerumus dalam dosa dan untuk melindungi anak yang masih di dalam kandungan calon istri.

Kemudian majelis hakim mendengarkan keterangan yang diberikan oleh calon besan Pemohon dalam persidangan yang pada pokoknya keterangan tersebut menguatkan dalil permohonan Pemohon, kemudian Pemohon juga menghadirkan dua orang saksi, kedua saksi tersebut telah memenuhi syarat materiil sebagai saksi, sebagaimana yang diatur dalam ketentuan Pasal 171 HIR sehingga keterangan kedua saksi tersebut sudah memiliki kekuatan pembuktian dan dapat diterima sebagai alat bukti.

Pertimbangan hakim berdasarkan surat permohonan Pemohon, keterangan anak Pemohon beserta calon suami atau calon istri anak Pemohon, keterangan calon besan Pemohon dan kemudian didukung dengan adanya alat bukti berupa foto kopi identitas Pemohon, kutipan akta nikah Pemohon, kartu keluarga Pemohon, akta kelahiran anak Pemohon, surat keluarga calon besan, surat pemberitahuan adanya halangan/kekurangan pernikahan, surat penolakan dari Pegawai Pencatat Nikah (PPN) Kantor Urusan Agama Kecamatan, Kabupaten Nganjuk, yang telah diperiksa dan dicocokkan sesuai dengan aslinya serta keterangan dua orang saksi yang telah di hadirkan oleh Pemohon. Serta berpedoman pada kaidah fikih yang artinya "mencegah 
kerusakan harus didahulukan dari pada pencapaian nilai - nilai maslahah."

Majelis hakim beralasan untuk memberikan izin dispensasi nikah kepada anak Pemohon untuk pemenuhan kekurangan persyaratan adminitrasi dalam Pencacatan pernikahan di Kantor Urusan Agama Kecamatan Kabupaten Nganjuk. Fakta di lapangan, dari 44 permohonan dispensasi nikah tidak semua dikabulkan. Ada 1 permohonan dispensasi nikah digugurkan dikarenakan Pemohon tidak pernah hadir dalam persidangan dalam menyelesaikan permohonan yang digugurkan majelis hakim berpedoman pada ketentuan Pasal 124 HIR. $^{31}$ Kemudian 1 permohonan dispensasi nikah dicabut oleh Pemohon dalam menyelesaikan permohonan yang dicabut majelis hakim berpedoman pada ketentuan Pasal $271 \mathrm{Rv}{ }^{32}$

Selanjutnya mengenai biaya perkara berdasarkan ketentuan Pasal 89 ayat (1) UU No. 7 Tahun 1989 tentang Peradilan Agama yang telah diubah dengan UU No. 3 Tahun 2006 dan perubahan kedua dengan UU No. 50 Tahun 2009. Biaya perkara dibebankan kepada Pemohon dikarenakan perkara dispensasi nikah termasuk bidang perkawinan dan termasuk dalam kewenangan absolut Pengadilan Agama Nganjuk. ${ }^{33}$ Berdasarkan keterangan mengenai jumlah permohonan dispensasi nikah di Pengadilan Agama Nganjuk Tahun 2015 terdapat 44 permohonan dispensasi nikah, dari 44 permohonan dispensasi nikah terdapat 7 Hakim di Pengadilan Agama Nganjuk Tahun 2015 dari 7 Hakim tersebut maka terbentuk 5 majelis Hakim yang menyelesaikan perkara permohonan dispensasi nikah di Pengadilan Agama Nganjuk Tahun 2015.

Dalil hukum hakim merupakan dalil yang digunakan oleh hakim untuk memutuskan suatu perkara. Dalil hukum hakim ini mempengaruhi keabsahan sutau perkara. Dari dalil hukum ini dapat diketahui tentang sumber hukum hakim dalam memutuskan

${ }^{31}$ Salinan Penetapan No. 0026/Pdt.P/2015/PA.Ngj, 3.

32 Ibid,...,No. 0060/Pdt.P/2015/PA.Ngj, 3.

33 Pasal 89 ayat (1) Undang -Undang No. 7 Tahun 1989, Tentang Peradilan Agama. 
suatu perkara, ${ }^{34}$ sebagaimana dalil hukum hakim yang digunakan dalam memberikan penetapan permohonan dispensasi nikah di Pengadilan Agama Nganjuk Tahun 2015.

\section{Analisis Terhadap Dalil Hukum Hakim dalam Penetapan Permohonan Dispensasi Nikah di Pengadilan Agama Nganjuk Tahun 2015}

Berdasarkan dalil hukum hakim dalam penetapan permohonan dispensasi nikah di Pengadilan Agama Nganjuk Tahun 2015 ditemukan bahwa pertimbangan hukum hakim dalam menyelesaikan permohonan penetapan dispensasi nikah menggunakan beberapa pertimbangan hukum hakim diantaranya :

Berdasarkan penolakan yang dilakukan oleh Pegawai Pencatat Nikah (PPN) Kantor Urusan Agama Kecamatan Kabupaten Nganjuk, telah sesuai dengan aturan perundangundangan yang berlaku di Indonesia, yakni terdapat pada ketentuan Pasal 7 ayat (1) UU No. 1 Tahun 1974 tentang Perkawinan "perkawinan hanya diizinkan jika pihak pria sudah mencapai umur 19 (Sembilan belas) tahun dan pihak wanita sudah mencapai usia 16 ( enam belas) tahun". 35

Apabila seseorang ingin melakukan pernikahan dan belum memenuhi batas ketentuan usia pernikahan, maka tidak bisa dilangsungkan pernikahan kecuali mendapatkan izin dispensasi nikah dari lembaga yang berwenang dalam hali ini Pengadilan Agama, sebagaimana sesuai dengan ketentuan Pasal 7 ayat (2) UU No. 1 Tahun 1974 tentang Perkawinan "dalam hal penyimpangan terhadap ayat (1) pasal ini dapat meminta dispensasi nikah ke pengadilan agama atau pejabat lain yang berwenang ditunjuk oleh salah kedua orang tua pihak pria maupun pihak wanita". ${ }^{36}$

Dispensasi ini berfungsi sebagai legalitas kedewasaan dan persyaratan untuk melakukan pernikahan bagi mereka yang secara undang-undang belum diperkenankan melakukan pernikahan. Pertimbangan hukum hakim selanjutnya berdasarkan ketentuan Pasal 4 UU No. 7 Tahun 1989 diubah dengan UU No. 3 Tahun

${ }^{34}$ M. Yahya Harahap, Hukum Acara Perdata, (Jakarta: Sinar Grafika, 2012), 57.

35 Pasal 7 ayat (1) Undang - undang No.1 Tahun 1974 tentang Perkawinan.

36 Ibid., ayat (2). 
2006 tentang Peradilan Agama, menyatakan bahwa Pengadilan Agama berkedudukan di Kabupaten atau Kota daerah hukumnya meliputi wilayah Kabupaten dan Kota. ${ }^{37}$ Maka majelis hakim berpendapat bahwa Pemohon telah memenuhi persyaratan untuk mengajukan permohonan dispensasi nikah di Pengadilan Agama Nganjuk. ${ }^{38}$

Ketentuan Pasal 4 UU No. 7 Tahun 1989, diubah dengan UU No. 3 Tahun 2006 tentang Peradilan Agama, menyatakan bahwa Pengadilan Agama berkedudukan di Kabupaten atau Kota daerah hukum Penggugat maupun Pemohon. ${ }^{39}$ Seseorang boleh melakukan permohonan dispensasi nikah di Pengadilan Agama Nganjuk berdasarkan bukti kartu tanda penduduk (KTP) yang telah dikeluarkan oleh dinas catatan sipil dan Kependudukan Kabupaten Nganjuk, maka permohonan Pemohon patut diterima berdasarkan kewenangan relatif Pengadilan Agama Nganjuk.

Mengenai keabsahan permohonan dispensasi nikah di Pengadilan Agama Nganjuk Tahun 2015 pertimbangan hukum majelis hakim berpedoman pada ketentuan Pasal 49 UU No. 7 Tahun 1989 yang telah diubah dengan UU No. 3 Tahun 2006 dan perubahan kedua dengan UU No. 50 Tahun 2009 tentang Peradilan Agama mengenai kewenangan absolut menyatakan bahwa Pengadilan Agama Nganjuk berwenang untuk memeriksa, mengadili dan menyelesaikan perkara permohonan dispensasi nikah berdasarkan materi hukum perkara tingkat pertama di Peradilan Agama. ${ }^{40}$ Berdasarkan ketentuan tersebut menjelaskan kewenangan Pengadilan Agama Nganjuk, dalam halnya mengenai perkara perdata Islam salah satunya permohonan dispensasi nikah, maka salah satu perkara yang ditangani Pengadilan Agama Nganjuk dalam hal ini mengenai permohonan dispensasi nikah patut diterima, berdasarkan kewenangan absolut Pengadilan Agama Nganjuk.

${ }^{37}$ Pasal 4 ayat (1) UU No. 7 Tahun 1989 diubah dengan UU No.3 Tahun 2006 tentang Peradilan Agama.

384 UU No. 7 Tahun 1989 diubah dengan UU No. 3 Tahun 2006 tentang Peradilan Agama.

39 Ibid.

40 Mardani, Hukum Acara Peradilan Agama dan Mabkamah Syariab, (Jakarta: Sinar Grafika, 2010), 53. 
Atas permohonan Pemohon majelis hakim telah memeriksa dan mempertimbangkan bahwa untuk mendapatkan izin dispensasi nikah di Pengadilan Agama Nganjuk adapun beberapa persyaratan yang harus dipenuhi diantaranya, foto kopi identitas Pemohon, kutipan akta nikah pemohon, kartu keluarga pemohon, akta kelahiran anak Pemohon, surat keluarga calon besan, surat pemberitahuan adanya halangan/kekurangan pernikahan, surat penolakan dari Pegawai Pencatat Nikah (PPN) Kantor Urusan Agama Kabupaten Nganjuk dan persyaratan tersebut sudah dipenuhi oleh Pemohon dan sudah dicocokkan dan sudah sesuai dengan aslinya, selanjutnya berdasarkan ketentuan Pasal 2 ayat (1) huruf a, ayat (2) dan ayat (3), Pasal 3, Pasal 10, dan Pasal 11 ayat (1) huruf a Undang - undang No.13 Tahun 1985 tentang Bea Materai, pasal 1 huruf a dan huruf $f$ serta Pasal 2 ayat (1) Peraturan Pemerintah No. 24 Tahun 2000 tentang Perubahan Tarif Bea Materai dan besarnya batas pengenaan harga nominal yang dikenakan bea materai, bukti -bukti yang tersebut dapat diterima sebagai alat bukti, selanjutnya keterangan yang diperoleh dari calon suami maupun calon istri, calon besan Pemohon, serta saksi yang telah dihadirkan di depan persidangan juga telah menguatkan dalil Permohonan dispensasi nikah.

Mejelis hakim dalam memberikan izin dispensasi nikah kepada Pemohon untuk bisa menikahkan anaknya meskipun usia anaknya tersebut masih dibawah ketentuan usia pernikahan. Dalam memutuskan maupun menetapkan suatu perkara harus mempunyai dasar hukum yang dipakai sebagai dasar untuk mengambil suatu keputusan maupun penetapan agar tidak merugikan pihak yang berperkara. Majelis hakim sebagai penegak hukum dan keadilan wajib mengadili, mengikuti, dan memahami nilai - nilai hukum dan rasa keadilan yang hidup dalam masyarakat. ${ }^{41}$

Menurut ketentuan undang - undang yang mengatur tentang seseorang boleh melakukan pernikahan, majelis hakim pada dasarnya tidak bisa memberikan izin karena anak Pemohon untuk menikah disebabkan anak Pemohon usianya masih dibawah ketentuan batas usia perkanikahan. Akan tetapi pada ketentuan Pasal 7 Ayat (2) UU No.1 Tahun 1974 tentang Perkawinan "dalam

${ }^{41}$ Pasal 28 ayat (1) UU No. 4 Tahun 2004 tentang Kekuasaan Kehakiman. 
hal penyimpangan terhadap ayat (1) pasal ini dapat meminta dispensasi nikah ke Pengadilan Agama atau pejabat lain yang berwenang ditunjuk oleh salah kedua orang tua pihak pria maupun pihak wanita." ${ }^{42}$ Meskipun dalam ketentuan Pasal 7 ayat (2) UU No.1 Tahun 1974 tentang Perkawinan, memberikan kemudahan terhadap seseorang yang ingin menikah akan tetapi usianya masih dibawah batas ketentuan usia pernikahan maka dapat meminta izin dispensasi nikah ke Pengadilan Agama.

Sebagaimana dalam kaidah fikih dijelaskan "mencegah kerusakan harus didahulukan dari pada pencapaian nilai nilia maslahat" berdasarkan ketentuan Pasal 1 UU No.1 Tahun 1974 tentang Perkawinan, menyatakan bahwa tujuan perkawinan sangatlah mulia. Akan tetapi apabila tujuan yang sangat mulia tersebut tidak disegerakan padahal antara calon suami maupun calon istri sudah siap membangun bahtera rumah tangga meskipun usia mereka belum mencapai usia ideal seseorang boleh melakukan pernikahan, maka akan menimbulkan fitnah maupun akan menimbulkan perbuatan yang tidak diingikan dikemudian hari.

Berkaiatan dengan wanita hamil diluar pernikahan, majelis hakim III dan majelis hakim IV memberikan kepastian hukum dalam ketentuan Pasal 53 Kompilasi Hukum Islam didalam memberikan penetapan permohonan dispensasi nikah di Pengadilan Agama Nganjuk Tahun 2015 pertimbangan majelis hakim III dan majelis Hakim IV tersebut yang menyatakan sebagai berikut:

\section{Pasal 53}

1. Seorang wanita hamil diluar nikah, dapat dikawinkan dengan pria yang menghamilinya.

2. Perwakina dalam keadaan hamil yang disebutkan pada ayat (1) dapat dilangsungkan tanpa menunggu lebih dahulu kelahiran anaknya.

3. Dengan dilangsungkanya perkawinan pada saat wanita hamil, tidak diperlukan perkawinan ulang setelang anak yang dikandungan lahir. ${ }^{43}$

42 Pasal 7 ayat (2) Undang - undang No. 1 Tahun 1974 tentang Perkawinan.

43 Pasal 53 Kompilasi Hukum Islam. 
Oleh karena itu, majelis hakim dalam memberikan izin dispensasi nikah di Pengadilan Agama Nganjuk Tahun 2015, persetujuan tersebut diberikan guna untuk mengabulkan permohonan Pemohon dan memberikan izin dispensasi nikah kepada Pemohon untuk menikahkan anak Pemohon dengan calon suami atau calon istri, selanjutnya pejabat yang berwenang dalam hal ini Pejabat Pencatat Nikah (PPN) Kantor Urusan Agama Kecamatan Kabupaten Nganjuk, agar dapat melaksanakan pernikahan mereka.

\section{Perbedaan Penggunaan Dalil Hukum Hakim dalam Memberikan Dispensasi Nikah di Pengadilan Agama Nganjuk Tahun 2015}

Meskipun sudah ada ketentuan mengenai batas usia pernikahan, ketentuan tersebut diatur didalam Pasal 7 ayat (1) UU No 1 Tahun 1974 tentang Perkawinan, namun dalam praktek penerapanya bersifat fleksibel yang artinya jika memang dalam keadaan mendesak atau keadaan darurat demi menghindari kerusakan atau mafsadah yang lebih besar dan harus didahulukkan mempertahankan kebaikan atau maslahah, maka kedua calon mempelai harus segera dinikahkan. Pertimbangan hukum hakim dalam memberikan penetapan permohonan dispensasi nikah di Pengadilan Agama Nganjuk Tahun 2015 terjadi perbedaan penggunaan dalil hukum hakim majelis hakim III dan majelis hakim IV mengenai wanita hamil di luar pernikahan majelis hakim III dan majelis hakim IV mempertimbangkan akibat hukum terhadap sahnya seorang anak yang ada di dalam kandungan wanita tersebut pertimbangan tersebut diambil dari ketentauan Pasal 53 Kompilasi Hukum Islam mengenai wanita hamil diluar pernikahan,

Pertimbangan hukum hakim tersebut mempertimbangkan seorang anak tidak berkehendak ataupun kemauan dari anak tersebut, bahkan seorang anak tidak pernah diberikan hak untuk memilih akan dilahirkan dari rachim milik siapa, seorang anak tidak memiliki kepentingan terhadap sahnya atau tidaknya suatu perkawinan orang tuanya dan mengganggu akibat dari perbuatan yang dilakukan oleh orang taunya. Karena kelahiran merupakan persoalan takdir yang tidak bisa dihindari oleh anak sehingga 
prinsipnya tidak akan ada suatu anak dilahirkan dari hubungan yang tidak sah. Dengan demikian, perlu adanya perlindungan dan kepastian hukum yang adil terhadap status keberadaan seorang anak sejak anak tersebut masih dalam kandungan hingga anak tersebut lahir nantinya.

Berdasarkan perlindungan dan kepastian hukum terhadap perlindungan seorang anak dan kepastian hukum selanjutnya mengenai hubungannya antara orang tua dan anak, menyatakan apabila perkawinan dilakanakan secara agama saja, dan tidak dicatatkan pada Pegawai Pencatatan Nikah (PPN) Kantor Urusan Agama (KUA), maka suami dapat saja mengingkari pernikahan tersebut. Untuk itu ketentuan yang terdapat dalam Pasal 2 ayat (1) dan ayat (2) UU No.1 Tahun 1974 tentang Perkawinan, merupakan satu kesatuan yang tidak dapat dipisahkan sebagai syarat sahnya suatu pernikahan. ${ }^{44}$

Seperti yang telah dijelaskan diatas bahwa pernikahan yang sah mengakibatkan hukum terhadap asal usul anak yang dilahirkan tersebut menjadi sah. Lebih lanjutnya di dalam ketentuan Pasal 43 UU No.1 Tahun 1974 tentang Perkawinan yang menyatakan "anak yang dilahirkan diluar pernikahan hanya mempunyai hubungan perdata dengan ibunya dan keluarga ibunya" . ${ }^{45}$

Berdasarkan pertimbangan hukum hakim tersebut, majelis hakim berpendapat bahwa perlindungan hukum terhadap anak yang ada dalam kandungan harus lebih diutamakan dengan mengesampingkan pasal 7 ayat (1) Undang - undang No.1 Tahun 1974, Jo Pasal 15 ayat (1) Kompilasi Hukum Islam. Berdasarkan pertimbangan - pertimbangan tersebut di atas, maka Pemohon yang anaknya sudah dalam keadaan hamil permohonan Pemohon cukup beralasan dan memenuhi syarat serta dasar hukum.

Adapula perbedaan penggunakan dalil hukum selanjutnya terdapat dalam penetapan dispensasi nikah apabila Pemohon menguasakan permohonan kepada penasehat hukum majelis hakim I, II, dan IV terlebih dahulu mempertimbangkan keabsahan surat

44 Moh. Idris Ramulyo, Hukum Perkawinan, Hukum Kewarisan, Hukum Acara Peradilan dan Hukum Zakat Menurut Hukum Islam, ( Jakarta: Sinar Grafindo, 1995), 49.

45 Pasal 43 Undang - undang No. 1 Tahun 1974, tentang Perkawinan . 
kuasa yang dikuasakan oleh Pemohon kepada penasehat hukum tersebut. Pertimbangan majelis hakim tersebut terdapat didalam buku pedoman pelaksanan tugas dan fungsi adminitrasi peradilan Agama buku II edisi revisi yang menyatakan bahwa kuasa hukum yang bertidak sebagai kuasa/wali dari pemohon/termohon atau termohon atau termohon di Pengadilan salah satu diantaranya adalah penasehat hukum sesuai dengan ketentuan Pasal 2 UU No. 18 Tahun 2003

Selanjutnya majelis hakim didalam memberikan izin dispensasi nikah di Pengadilan Agama Nganjuk Tahun 2015, majelis hakim IV juga dilengakapi dengan penambahan penggunaan dalil hukum hakim yang mengambil dari kitab suci alQur'an dalam Surah annur Ayat 32.

\section{Tinjauan Hukum Islam Terhadap Penetapan Majelis Hakim dalam memberikan izin dispensasi nikah di Pengadilan Agama Nganjuk Tahun 2015\}

Majelis hakim dalam memberikan penetapan permohonan dispensasi, majelis hakim tidak hanya perpedoman pada perundang - undangan yang berlaku, melainkan menggunakan pendekatan metodologi pengkajian hukum Islam. Mengenai permohonan dispensasi nikah perlu mempertimbangkan maslahah mursalah, motode ijtihad dalam hukum Islam berdasarkan kemaslahahtan umum. ${ }^{46}$ Hakim mengedepankan konsep maslahah mursalah yaitu pertimbangan kebaikan dan menolak kerusakan dalam permohonan dispensasi nikah serta upaya mencegah kemudhorotan.

Berdasarkan keterangan yang sudah disampaikan di muka persidangan antara anak Pemohon dan calon suami dan calon istri tidak ada halangan pernikahan untuk menikah, menimbang bersadarkan keterangan saksi - saksi tersebut dihubungkan dengan dalil Pemohon, maka majelis hakim menilai bahwa anak Pemohon dipandang layak untuk menikah dengan calonnya untuk menghindari hal - hal yang tidak di inginkan, karena keduanya sudah saling mencintai, dalam hal seperti ini hakim tidak kuasa

46 Zainudin Ali, Hukum Perdata Islam di Indonesia, (Jakarta: Sinar Grafika, 2006), 14. 
menolak untuk memberikan dispensi nikah karena ditakutkan jika permohonannya ditolak akibatnya lebih besar.

\section{Penutup}

Pertimbangan hukum majelis hakim dalam memberikan izin dispensasi nikah berpedoman pada ketentuan pasal 7 ayat (2) UU No.1 Tahun 1974 tentang Perkawinan "dalam hal penyimpangan terhadap ayat (1) pasal ini dapat meminta dispensasi nikah ke Pengadilan Agama atau pejabat lain yang berwenang ditunjuk oleh salah kedua orang tua pihak pria maupun pihak wanita". ${ }^{47}$ Kaidah fikih yang artinya "mencegah kerusakan harus didahulukan dari pada pencapaian nilai - nilai maslahah." Pertimbangan terhadap perlindungan dan kepastian hukum terhadap keberadaan anak, mengenai wanita hamil diluar nikah, maka permohonan Pemohon patut dikabulkan.

Terjadinya Perbedaan penggunaan dalil hukum hakim disebabkan, pertimbangan hukum majelis hakim III, dan IV memberikan perlindungan dan kepastian hukum terhadap keberadaan anak dengan memberikan penggunan dalil hukum hakim Pasal 53 ayat (1) Kompilasi Hukum Islam, mengenai Pemohon menguasakan permohonan kepada penasehat hukum mempertimbangkan ketentuan Pasal 2 UU No.18 2003 tentang Advokat, dan mengenai permohonan yang digugurkan dan dicabut mempertimbangkan pasal $124 \mathrm{HIR}$ dan pasal $271 \mathrm{Rv}$.

Pertimbangan majelis hakim dalam memberikan izin dispensasi nikah di Pengadilan Agama Nganjuk Tahun 2015 telah sesuai dengan hukum Islam karena bila mana permohonan tidak dikabulakan akan menimbulkan kerusakkan yang lebih luas sesuai dengan kaidah fikih yang artinya "mencegah kerusakan harus didahulukan dari pada pencapaian nilai nilia maslahah."

\section{Daftar Pustaka}

Imam al-Hijaj Abi Muslim. Shabih Muslim. Beirut: Darul Fikr, 1992 Departemen Agama RI. Al-Qur'an dan Terjemahannya. Bandung: CV Penerbit J-Art, 2005.

47 Pasal 7 ayat (2) Undang - undang No.1 Tahun 1974 tentang Perkawinan. 
Zainudin Ali. Hukum Perdata Islam di Indonesia. Jakarta: Sinar Grafika, 2006.

Roihan A Rasyid. Hukum Acara Peradilan Agama. Cet. IV. Jakarta: Raja Grafindo Persada, 1998.

Mukti Arto. Praktek Peradilan Pada Pengadilan Agama, Jogjakarta: Pustaka Pelajar, 2006.

Ari kunto, Suharmisi. Penelitian Suatu Pendekatan Praktek, cet XIV, Jakarta: Rineka Cipta, 2010.

Aisyah Dahlan. Persiapan Menuju yang Lestari. Jakarta: PT. Pustaka Antara, 1996.

Muhammad Fauzi Adhim. Indabnya Pernikahan Dini. Jakarta: Gema Insani, 2004.

Iqbal Hasan. Analisis Data Penelitian dengan Statistik. Jakarta: Bumi Askara,2006.

Sutrisno Hadi. Motodologi Riset. Jogjakarta: Yayasan Penerbit Psikologi UGM, 1982.

Moh Idris Ramulyo. Hukum Perkawinan, Hukum Kewarisan, Hukum Acara Peradilan dan Hukum Zakat Menurut Hukum Islam, Jakarta: Sinar Grafido, 1995.

------, Hukum Perkawinan Islam, Jakarta: Sinar Grafindo, 1999.

Asafri Jaya Bakti. Konsep Maqosid Syari'ah al-Syatibi. Jakarta: Raja GrafindoPersada, 2002.

Kansil, C.S.T dan Chistine S.T Kansil. Kamus Istilah Aneka Ilmu, Cet Ke-2. Jakarta: Surya Multi Grafika, 2001.

Mardani. Hukum Acara Perdata Peradilan Agama dan Mabkamah Syariah. Jakarta: Sinar Grafika, 2010.

Masruhan. Metodologi Hukum, Surabaya. Hilal Pustaka, 2013.

Muslim, Imām. Sabib Muslim. Juz 5. Beirut: Dārul Kutub Ilmiyah, Cet II, 2008.

Husain Muhammad. Fiqih Perempuan, Refleksi kiai atas Wacana Agama dan Gender), Jogjakarta: LKiS, 2007.

Mudzakaro. Tentang Perkawinan di Bawah Umur. Jakarta: Al- Azhar, 1985.

Ahmad Mujahidin. Pembaharuan Hukum Acara Perdilan Agama. Bogor: Gralia Indonesia, 2012.

Abdul Manan. Etika Hakim dalam Penyelenggaraan Peradilan, Jakarta: Kencana, 2007. 
Moh Nazir. Metodologi Penelitian. Bogor: Ghalia Indonesia, 2009.

Pelaksaan Tugas Pedoman dan Adminitrasi Peradilan Agama Edisi Revisi, Buku II, (Direktoral Jenderal Badan Peradilan Agama, 2010.

Penyususunan Tim dan Pengembangan Bahasa. Kamus Besar Bahasa Indonesia. Jakarta: Balai Pustaka, 1988.

M Quraish Shihab. Tafsir al Misbāh. Cet. IV. Vol. IX. Jakarta : Lentera Hati, 2005.

Abd Rahman Dahlan. Usul Fiqih. Jakarta: Amzah, 2010.

Ahmad Rofik. Hukum Islam di Indonesia. Jakarta: PT Raja Grafindo Persada, 2003.

Umar Said. Hukum Acara Peradilan Agama, Surabaya: Cempaka, 2004.

Sudarsono. Kamus Hukum. Jakarta: Rineka Cipta, 1992.

Bambang Sunggono. Metodologi Penelitian Hukum. Jakarta: PT Raja Grafindo,1997.

Soemiyati. Hukum Perkawinan Islam dan Undang-Undang Perkawinan. Yogjakarta, Liberty, 1986.

Amir Syarifuddin. Hukum Perkawinan Islam di Indonesia. Antara Fikih Munakahat dan Undang-undang Perkawinan, Jakarta: Kencana, 2007.

M Yahaya Harahap. Kedudukan Kewenangan dan Acara Peradialan Agama, Jakarata: Sinar Grafika, 2003.

--------, Hukum Acara Perdata, Jakarta: Sinar Grafika cetakan ke XII, 2012.

Mahmud Yunus. Hukum Perkawinan dalam Islam. Jakarta : Hidakarya Agung. 1985.

Wahbah Zuhailiy. Ushul Fiqh al-Islamiy. Dimsyaq: Dar al- Fikr, 1998.

Moh Zahid. Dua Pulub Tabun Pelaksanaan Undang-Undang Perkawinan. Jakarta: Departemen Agama RI Badan Litbang Agama dan Diklat Keagamaan, 2002.

UU No.1 Tahun 1974. Tentang Perkawinan.

UU No. 3 Tahun 2006 atas Perubahan Undang - Undang No

No.7 Tahun 1989 Tentang Peradilan Agama.

UU No. 4 Tahun 2004 Tentang Kekuasaan Kehakiman.

UU No.18 Tahun 2003 Tentang Advokat. 
Peraturan Menteri Agama Nomor 3 Tahun 1975.

Kompilasi Hukum Islam. 